\title{
Physical and oxidative stability of high-fat fish-oil emulsions added algae-based stabilizers from Saccharina latissima
}

Hermund, Ditte Baun; Yesiltas, Betül; Anagnostara, loanna; Caindec, Alyssa Marie Soria ; Hou, Xiarou ; Neerup, Randi; Huang, Yuhong; Anasontzis, George E.; Lange, Lene; Jacobsen, Charlotte

\section{Publication date:}

2019

Document Version

Version created as part of publication process; publisher's layout; not normally made publicly available

Link back to DTU Orbit

Citation (APA):

Hermund, D. B., Yesiltas, B., Anagnostara, I., Caindec, A. M. S., Hou, X., Neerup, R., Huang, Y., Anasontzis, G. E., Lange, L., \& Jacobsen, C. (2019). Physical and oxidative stability of high-fat fish-oil emulsions added algaebased stabilizers from Saccharina latissima. Abstract from 30th Nordic Lipidpforum Symposium 2019, Horsens, Denmark.

\section{General rights}

Copyright and moral rights for the publications made accessible in the public portal are retained by the authors and/or other copyright owners and it is a condition of accessing publications that users recognise and abide by the legal requirements associated with these rights.

- Users may download and print one copy of any publication from the public portal for the purpose of private study or research.

- You may not further distribute the material or use it for any profit-making activity or commercial gain

- You may freely distribute the URL identifying the publication in the public portal 


\title{
Physical and oxidative stability of high-fat fish-oil emulsions added algae-based stabilizers from Saccharina latissima
}

Ditte Baun Hermund ${ }^{1} \star$, Betül Yesiltas ${ }^{1}$, Ioanna Anagnostara ${ }^{1}$, Alyssa Marie Soria Caindec ${ }^{1}$, Xiarou Hou $^{2}$, Randi Neerup ${ }^{3}$, Yuhong Huang ${ }^{3}$, George E. Anasontzis ${ }^{3}$, Lene Lange ${ }^{3}$, and Charlotte Jacobsen ${ }^{1}$

${ }^{1}$ National Food Institute, Technical University of Denmark, DK-2800 Kgs Lyngby, Denmark

${ }^{2}$ Danish Technological Institute, DK-2630 Taastrup, Denmark

${ }^{3}$ DTU Chemical Engineering, Technical University of Denmark, DK-2800 Kgs Lyngby, Denmark *Corresponding author: dbala@food.dtu.dk

\begin{abstract}
The protection of long-chain (LC) omega-3 polyunsaturated fatty acids (PUFAs) against oxidation when added into food matrices could be achieved by the development of fish-oil delivery emulsions and by the addition of antioxidants.

Commercial alginate, a brown algae polysaccharide, in combination with sodium caseinate (NaCas), is widely used by the food industry to stabilize emulsions. Moreover, previous studies have reported that laminarin and fucoidans, both brown-algae polysaccharides, show antioxidant activity.

In this work, alginate (NaAlg), fucoidan, and laminarin were extracted from the brown alga Saccharina latissima and examined for their stabilizing properties. The potential of these polysaccharides in preventing lipid oxidation and in maintaining the physical stability of $70 \%(\mathrm{w} / \mathrm{w})$ fish oil-in-water emulsions were studied. The polysaccharides were formulated in different concentration $(0-0.63 \%, w / w)$ together with NaCas $(0.23 \%$, $\mathrm{w} / \mathrm{w}$ ) into the aqueous phase. The physical (e.g. creaming, droplet-size distribution, and apparent viscosity) and oxidative (peroxide value and secondary oxidation products) stability of the emulsions, were evaluated during 12 days of storage in the dark at $20^{\circ} \mathrm{C}$.

Results showed that the antioxidant activity of fucoidan, laminarin and NaAlg derived from S. latissima in emulsion systems was only observed for laminarin and for some concentrations of NaAlg. It was found that laminarin was the most promising polysaccharide to enhance the oxidative stability of the emulsions. However, the physical stability of the emulsions added laminarin was poor at low concentrations. Hence, it can be recommended to use laminarin extracts for stabilizing $70 \%(w / w)$ fish oil-in-water emulsions both physically and oxidatively at a concentration of $0.30 \%(\mathrm{w} / \mathrm{w})$ together with $0.23 \%(\mathrm{w} / \mathrm{w}) \mathrm{NaCas}$.
\end{abstract}

